ANDRZEJ FURIER

\title{
KAUKAZ W POLSKICH PLANACH WALKI O NIEPODLEGLOŚĆ W XIX WIEKU
}

Obchodzone w 2018 r. stulecie odzyskania niepodległości przez Polskę stało się okazją do przypomnienia wysiłków patriotów, którzy w XIX wieku czynnie o nią zabiegali. Ważną częścią tych zabiegów była dobrze rozpoznana przez badaczy aktywność polityczna Wielkiej Emigracji ${ }^{1}$. Związana z nią polska obecność polityczna w Turcji od dawna stanowi obszar polskich badań naukowych. Duży wpływ na to ma rozległa baza źródłowa, stworzona przez uczestników tamtych wydarzeń, w gronie których było sporo literatów. Badania te rozwijały się szczególnie intensywnie w okresie międzywojennym, gdy zaangażowali się w nie najwybitniejsi polscy historycy - Marceli Handelsman i Ludwik Widerszal. Kontynuowali je potem kolejni badacze, żeby wymienić tylko Henryka Wereszyckiego, Jana Reychmana i Jerzego Skowronka. W zdecydowanej większości publikacji koncentrowano uwagę na Turcji i Bałkanach, dosyć powierzchownie traktując Kaukaz. Wyjątek stanowiły badania Ludwika Widerszala, które po dzień dzisiejszy nie tracą znaczenia ${ }^{2}$.

Polska aktywność polityczna na tzw. muzułmańskim Wschodzie obejmowała w XIX wieku Turcję i Kaukaz, pozostawiając na uboczu ważną wcześniej dla naszych władców Persję. Kaukaz miał znaczenie drugorzędne, a mimo to zajmował istotne miejsce w polskich staraniach o poszerzenie obszaru walki niepodległościowej. Naukowcy w Polsce zainteresowali się Kaukazem już w okresie międzywojennym, ograniczyli jednak swoje wysiłki do pierwszej połowy XIX stulecia, opierając je głównie na dokumentach z polskich i zachodnich archiwów. Najciekawszą próbę przedstawienia zarysu polityki europejskiej wobec Kaukazu w okresie mię-

Prof. dr hab. ANDRzej FurIeR - Instytut Nauk o Polityce i Bezpieczeństwie na Wydziale Nauk Społecznych Uniwersytetu Szczecińskiego; e-mail: andrzejfurier@interia.pl

${ }^{1}$ Por. S. KalemBKa, Wielka Emigracja. Polskie wychodźstwo polityczne w latach 1831-1862, Warszawa 1971.

${ }^{2}$ L. WIDERSZAL, Sprawy kaukaskie w polityce europejskiej w latach 1831-1864, Warszawa 1934, reprint: Warszawa 2011 (seria Klasycy Historiografii Warszawskiej). 
dzypowstaniowym przedstawił Ludwik Widerszal już w 1936 r. Wśród ogłoszonych drukiem później wyników badań naukowych na ten temat, warty uwagi jest artykuł poświęcony aktywności Hotelu Lambert w latach 1832-1840, który został napisany przez badacza polityki księcia Adama Jerzego Czartoryskiego ${ }^{3}$.

W Polsce z mniejszą uwagą analizowano wydarzenia na Kaukazie z lat poprzedzających wybuch powstania styczniowego, chociaż w ostatnim czasie pojawiły się publikacje poświęcone także temu obszarowi polityki Hotelu Lambert. Ich autorzy bardzo rzadko sięgają po archiwalia rosyjskie, opierając analizę na znanych od dawna polskich źródłach. To istotny brak polskich badań tej problematyki. Poczynając od najpełniejszego opracowania L. Widerszala, w polskich publikacjach mamy do czynienia z dużym brakiem precyzji, wynikającym ze słabej znajomości Kaukazu. Jest to także jeden z powodów pojawienia się dosyć oderwanych od rzeczywistości publikacji, także o charakterze publicystycznym, prezentujących wymyślone polsko-kaukaskie braterstwo broni w wieku XIX. Nie opierają się one na dokumentach i nie uwzględniają ani wewnątrzkaukaskich podziałów, ani wynikających z nich istotnych różnić dzielących Polaków z mieszkańcami tego regionu. O ile bowiem historycznie ugruntowana jest nasza bliskość z chrześcijańskimi Ormianami i Gruzinami, o tyle znacznie mniej łączyło Polaków w XIX wieku z wyznającymi islam góralami mieszkającymi na Kaukazie Północnym. Artykuł uwzględniając wskazane elementy, podejmuje próbę uzupełnienia naszej wiedzy na temat znaczenia Kaukazu dla polskiej walki o niepodległość w XIX wieku i sensu polskiej aktywności politycznej na jego terenie ${ }^{4}$.

\section{TURCJA I KAUKAZ W XIX WIEKU}

Kaukaz od średniowiecza był obszarem tureckiej i perskiej aktywności politycznej. Te dwa azjatyckie mocarstwa podporządkowały sobie wtedy najcenniejsze gospodarczo tereny Kaukazu Południowego, z czasem rozciągając swoje wpływy także na część Kaukazu Północnego. W kolejnych stuleciach poddano je represyjnej polityce islamizacji i wyzysku ekonomicznego. Najbardziej odczuli to kaukascy chrześcijanie, ale także $\mathrm{w}$ relacjach $\mathrm{z}$ kaukaskimi muzułmanami doprowadziło to do dużych napięć. Istotne znaczenie odgrywały tu różnice rytów dzielących sun-

${ }^{3}$ R. ŻurawsKi vel GrajewsKi, Kaukaz w ,dyplomacji” księcia Adama Jerzego Czartoryskiego w okresie kryzysu wschodniego (1832-1840), „Przegląd Nauk Historycznych” 2(2003), nr 2, s. 181-198.

${ }^{4}$ A. FurIER, Wielokulturowość Kaukazu. W poszukiwaniu genezy zróżnicowania kulturowego regionu, „Sprawy Narodowościowe” (Seria nowa) 1999, z. 14-15, s. 205-210; TENżE, Historyczne aspekty kulturowego zróżnicowania Kaukazu, „Sprawy Narodowościowe” (Seria nowa) 2000, z. 1617 , s. 53-72. 
nicką Turcję z kaukaskimi muzułmanami, których część należała do rytu sunnickiego szkoły szafi'ckiej i kierowała się zasadami sufizmu. Silne wpływy mieli tam także zwolennicy wahabizmus.

Obszarem polskiej aktywności politycznej i ekonomicznej Kaukaz stał się od XVI wieku, ale wzrost jego znaczenia politycznego dla polskiej dyplomacji nastąpił w kolejnych dwóch stuleciach. Wtedy polscy politycy szukali na Kaukazie i w Persji sojuszników w walce z Turcją. Cezurą kończącą ten okres była odsiecz Wiednia w 1683 r., co zauważył polski historyk analizując stosunki polsko-tureckie od tego wydarzenia do rozbiorów Rzeczypospolitej ${ }^{6}$. Bardziej precyzyjne jest rozpoczęcie okresu współpracy Polski z Turcją wraz z podpisaniem traktatu pokojowego 26 stycznia 1699 r. w Karłowicach, który formalnie zamknął okres wojen Rzeczypospolitej z Imperium Osmańskim i wyznaczał nowe zasady stosunków wzajemnych ${ }^{7}$.

Charakter relacji polsko-tureckich zmienił się radykalnie w czasie rozbiorów Polski, gdy Porta Otomańska z wroga stała się jej potencjalnym sojusznikiem. W tym państwie znaleźli schronienie konfederaci barscy i tam trafiali poszukujący wsparcia w walce z zaborcami wojskowi i emisariusze, jak Józef Sułkowski ${ }^{8}$. Przemiany te zbiegły się w czasie z rozpoczęciem procesu przyłączania Kaukazu przez Rosję, która w XIX wieku wyszła zwycięsko z rywalizacji o ten region, pokonując Turcję i Persję. Różnica między podporządkowaniem Kaukazu i rozbiorami Polski obejmowała czas i formę obu procesów. Rozbiorów Polski dokonały trzy sąsiednie mocarstwa, w trzech etapach wyznaczonych latami - 1772, 1793, 1795. Przedzielała je uchwalona 3 maja 1791 r. Konstytucja, która dowodziła ogromnego potencjału modernizacyjnego Polski. Natomiast Kaukaz Rosja przyłączyła samodzielnie, a proces był rozciągnięty w czasie na osiem dekad - od traktatu georgijewskiego z 1783 r. o protektoracie nad Gruzją do zakończenia wojny kaukaskiej w 1864 r. Innej szansy na ochronę przed zaborczością sąsiadów z południa region ten nie miał.

Wojny toczone przez Rosję na Kaukazie w XIX wieku zwróciły uwagę polskich działaczy niepodległościowych, którzy dostrzegli w nich szansę sojuszu z siłami, które przeciwstawiały się poszerzaniu obszaru rosyjskiego panowania.

${ }^{5}$ M. Roszczyn, Islam w Rosji: umma dopiero się rodzi, „Nowa Polityka Wschodnia” 2013, nr 3-4, s. 66-67.

${ }^{6}$ Por. W. KonopczyŃsKi, Polska a Turcja 1683-1792, Warszawa 1936, reprint: Kraków 2013.

${ }^{7}$ Formalnie był to traktat zawarty przez państwa Ligii Świętej zawiązanej w 1684 r. i Imperium Osmańskie. Por. A. FurIer, Polska aktywność dyplomatyczna w Turcji, Persji i na Kaukazie w XVI i XVII wieku, [w:] Systemy polityczne i kultura prawna państw azjatyckich, red. J. Marszałek-Kawa, M. Bidziński, Torun 2018, s. 204-232; A. FurIER, Polska aktywność polityczna w Turcji, Persji i na Kaukazie w XVIII wieku, [w:] Bliski Wschód-czynniki i skutki destabilizacji, red. B. Grenda, J. Marszałek-Kawa, Torun 2019, s. 156-176.

8 J. ReYchman, Życie polskie w Stambule w XVIII wieku, Warszawa 1959, s. 217-241. 
Takim państwem była Turcja, gdzie polska aktywność polityczna od czasu rozbiorów opierała się na wykorzystaniu poparcia francuskiego i angielskiego. Od końca XVIII wieku polskie działania nabierały intensywności i były kontynuowane w wieku XIX. Najaktywniej Polacy działali w trzech dekadach obejmujących okres między powstaniami listopadowym i styczniowym. Początkowo rozwijali działania dyplomatyczne, a później także współpracę wojskową z tworzeniem oddziałów wojskowych włącznie. Polskich polityków najbardziej interesowały dwa obszary potencjalnej akcji politycznej i militarnej - Bałkany i Kaukaz. O ile pierwszy został dosyć szczegółowo zbadany, to nadal niewiele wiemy o drugim.

Droga Polaków przebywających w Europie Zachodniej na Kaukaz wiodła przez Turcję, która podjęła z powodzeniem na początku XIX wieku wysiłek przeprowadzenia reform wewnętrznych. Umożliwiły one modernizację państwa. Na tle tych przemian z pierwszej połowy XIX wieku w Turcji, słabe i podzielone wewnętrznie państwa kaukaskie, całkowicie podporządkowane Rosji nie były najlepszym kandydatem na sojusznika sprawy polskiej. Natomiast Turcja, w której o dominację walczyły Francja z Wielką Brytanią, zasługiwała na rozwinięcie przez Polaków aktywnej polityki. Dlatego kierujący polską aktywnością na forum międzynarodowym książę Adam Jerzy Czartoryski wysyłał tam już na początku lat 30. polskich doradców wojskowych i planował zorganizowanie oddziałów wojskowych, które czynem zbrojnym miały poprzeć polskie aspiracje niepodległościowe. W umysłach Polaków ciągle żywe były wspomnienia z roku 1797, gdy w ciągu trzech miesięcy od podpisania przez gen. Jana Henryka Dąbrowskiego porozumienia w sprawie utworzenia polskiego legionu we Włoszech zgłosiło się ponad 3600 żołnierzy. Tamte doświadczenia próbowano wykorzystać także w działaniach prowadzonych na Wschodzie 9 .

W orbicie zainteresowań agentów Adama Jerzego Czartoryskiego był sąsiadujący z Turcją Kaukaz, na który pierwsza polska wyprawa była planowana w 1835 r. Chociaż nie doszła ona do skutku, to tocząca się tam wojna kaukaska nadal przyciągała uwagę polskich działaczy niepodległościowych. Trzeba zaznaczyć, że wojna ta została dobrze rozpoznana przez rosyjskich badaczy. W jej rosyjskich opisach dominują publikacje sławiące dokonania rosyjskiej armii. Polską odpowiedzią na to było mitologizowanie rzeczywistości kaukaskiej i walczących tam z Rosją górali. Tworzyło to platformę dla wysiłków skierowanych na wykazanie wspólnej, polsko-kaukaskiej walki z Rosją w XIX wieku. Wykorzystując stereotypy i romantyczne mity, próbowano intelektualnie zrównoważyć bolesną rzeczywistość, w której wielotysięczna grupa Polaków służących w szeregach

${ }^{9}$ Do tego upamiętnionego w polskim hymnie legionu zgłosili się polscy żołnierze z obozów jenieckich i oficerowie przebywający na emigracji. Por. J. PACHOŃSKI, Generał Jan Henryk Dąbrowski 1755-1818, Warszawa 1985. 
armii rosyjskiej była zmuszona do walki z góralami i realizowania na Kaukazie celów politycznych zaborcy ${ }^{10}$.

\section{POCZĄTKI POLSKIEJ AKTYWNOŚCI KAUKASKIEJ}

Przez sarmacką modę na orientalne stroje, tekstylia i uzbrojenie Kaukaz był obecny w świadomości polskiej szlachty. Jednak w XIX wieku dokonała się istotna zmiana w jego postrzeganiu, bo polscy działacze polityczni przestali fascynować się orientalnymi ozdobami, a zauważyli możliwość wykorzystania tego regionu w walce o niepodległość Polski. Rozciągający się od gruzińskiego wybrzeża Morza Czarnego ku wschodowi do Morza Kaspijskiego Kaukaz zamieszkiwały ludy, z wyjątkiem Ormian, słabo znane Polakom. Tylko nieliczni polscy politycy posiadali dobrą znajomość problematyki kaukaskiej. Wyjątek stanowił książę Adam Jerzy Czartoryski, który doceniał możliwości, jakie dawał Kaukaz sprawie polskiej. Zawdzięczał to kontaktom, które nawiązał w czasie pełnienia obowiązków ministra spraw zagranicznych Cesarstwa Rosyjskiego w latach 1804-1806. Przebywał wówczas w Petersburgu, gdzie poznał gruzińskich arystokratów, którzy trafili tam kilka lat wcześniej - po przyłączeniu Królestwa Wschodniej Gruzji do Rosji. Znał też rosyjskich wojskowych, którzy realizowali wtedy carską politykę na Kaukazie. Dzięki temu rozumiał znaczenie tej peryferyjnej części Cesarstwa Rosyjskiego w stosunkach międzynarodowych ${ }^{11}$.

Odnalezione dokumenty potwierdzają, że A.J. Czartoryski dobrze poznał Gruzję i kraje Kaukazu Południowego już w pierwszej dekadzie XIX wieku. Dowodzi tego korespondencja prowadzona przez niego z dowodzącym przez kilka lat wojskami rosyjskimi na Kaukazie generałem Pawłem Cycjanowem. Wojskowy ten realizował rosyjską politykę aneksji ziem kaukaskich, od objęcia tam stanowiska dowódcy piechoty w 1802 r., do śmierci w czasie walk o Baku 20 lutego 1806 r. Dlatego dobrze orientował się w sytuacji politycznej regionu. Odnalezione listy P. Cycjanowa do księcia A.J. Czartoryskiego ujawniają jego duże zainteresowanie kaukaskimi sprawami politycznymi i militarnymi już na początku XIX wieku. Rosyjski generał zwracając się do księcia w języku francuskim „Mon cher Prince” lub polskim „Wojewodo”, opisywał działania dowodzonych przez siebie wojsk w po-

${ }^{10}$ Polemika z tym nurtem [w:] A. FurIER, Polskie ślady w czeczeńskiej historii, „Przegląd Polonijny” 21(1995), z. 3(77), s. 17-34; A. FurIER, Czeczenia i jej mieszkańcy w oczach Polaków, „Etnografia Polska" 41(1997), z. 1-2, s. 121-146.

${ }^{11}$ W zbiorach Muzeum Historyczno-Etnograficznego w Zugdidi zachował się list księcia Adama Czartoryskiego do księżnej Nino Dadiani. List księcia Adama Czartoryskiego do księżnej Nino, 31 maja 1806 r., zbiór rękopisów. 
tyczkach z Czeczenami i w walkach o Derbent nad Morzem Kaspijskim. Napisane przez niego kiepską francuszczyzną listy upstrzone są dopiskami po polsku, co wskazuje, że P. Cycjanow znał ten język; a przynajmniej tak mu się wydawało ${ }^{12}$.

Poznanie kaukaskich realiów politycznych przez księcia Adama Jerzego Czartoryskiego wpłynęło na wzrost jego zainteresowania regionem, gdy zaczął prowadzić polską politykę zagraniczną w latach 30 . XIX wieku. Wtedy na Kaukaz trafili jego pierwsi agenci, którzy początkowo wykonywali zadania wywiadowcze. Ich celem było zbieranie informacji na temat aktualnej sytuacji politycznej i nawiązywanie kontaktów z ludami kaukaskimi. Osobne miejsce zajmowały wysiłki, mające na celu nawiązanie kontaktu z Polakami służącymi w Korpusie Kaukaskim. Ta aktywność od początku była związana z działaniami angielskimi, co stanowiło kontynuację podjętej przez polską emigrację próby obnażania na Zachodzie celów i metod imperialnej polityki rosyjskiej. Uwagę zwraca w tej dziedzinie akcja szkockiego pisarza i dyplomaty Dawida Urquharta - od 1835 r. sekretarza angielskiej ambasady w Stambule (noszącym wtedy nazwę Konstantynopol), który wydawał wspólnie z Polakami w języku angielskim i francuskim pismo „Portofolio”. Niektóre jego numery przetłumaczono na języki ludów kaukaskich i wykorzystano jako materiał propagandowy, rozpowszechniany na Kaukazie. Odgrywające w tych działaniach ważną rolę pismo było wydawane w Anglii, a współpracował z nim ksiądz Adam Karol Sienkiewicz, pełniąc w nim obowiązki sekretarza ${ }^{13}$.

Metodą działania stosowaną przez polskich agentów na Kaukazie było przerzucanie tam egzemplarzy „Portofolio” zaopatrzonych we własne komentarze. Dotyczyło to także wydawanego w Londynie i Genewie przez Aleksandra Hercena w latach 1857-1867 pisma rosyjskich emigrantów „Kołokoł”. Kolportowanie go na Kaukazie miało na celu wpływanie na oficerów Korpusu Kaukaskiego ${ }^{14}$.

W akcji propagandowej prowadzonej na Kaukazie wykorzystywano dokumenty dostarczone Anglikom przez Polaków, pochodzące z archiwum wielkiego księcia Konstantego. Zostały one zdobyte w czasie powstania listopadowego przez Polaków i przekazane brytyjskiemu ministerstwu spraw zagranicznych. Ujawniały metody działania Rosji i ukazywały agresywny charakter polityki rosyjskiej. W „Portofolio” publikowano także różne proklamacje i deklaracje, dotyczące np. niepodległości modnej wtedy na Zachodzie Czerkiesji. Trzeba wyjaśnić, że na

${ }_{12}$ Listy napisane przez P. Cycjanowa do J.A. Czartoryskiego w latach 1802-1804 przechowuje Biblioteka Książąt Czartoryskich [dalej: BCz], sygn. 5539 III, pudło 219, Korespondencja księcia Adama Czartoryskiego.

${ }^{13}$ Por. D. URquhart, The secret of Russia in the Caspian and Euxine. The Circassian war as affecting the insurrection in Poland 1863 (unknown binding); reprint: Franklin 2019.

${ }^{14}$ H. WeresZyCKI, Stosunki Hotelu Lambert z Hercenem i Bakuninem w przeddzień powstania styczniowego, „Przegląd Historyczny” 1957, nr 2, s. 251-254. 
Zachodzie używano wówczas tej nazwy dla zbiorczego określenia mieszkańców Kaukazu Północnego, w jego zachodniej, nadczarnomorskiej części. W rzeczywistości Czerkiesi są ludem należącym do grupy adygejskiej, który zajmuje ziemie na południowym brzegu rzeki Kubań ${ }^{15}$.

Celem akcji prowadzonej przez agentów polskich i angielskich było podburzanie ludów kaukaskich do walki z Rosją. Ważnym elementem tych wysiłków było zawarcie porozumienia o współpracy z rosyjskimi emigrantami - Aleksandrem Hercenem i Michaiłem Bakuninem, którzy także rozwijali własną akcję informacyjną i wywiadowczą na terenie Kaukazu. Rosjanie byli pod wrażeniem sprawności działań Polaków na terenie Turcji i utrzymywali intensywne kontakty z polską emigracją. M. Bakunin zaproponował nawet wykorzystanie swoich kontaktów i agenta Kisieljewa w celu włączenia do polskiej akcji na Kaukazie środowiska rosyjskich starowierców, którym przewodził niejaki Gonczarow ${ }^{16}$. Trzeba wyjaśnić, że ta sekta religijna została tam przesiedlona przez władze carskie podobnie jak inne wspólnoty wyznaniowe uznane przez władze za nieprawomyślne. Dla obrony przed napadami górali kaukaskich utworzyli oni własne oddziały zbrojne, które kontrolowały sytuację na terenach zamieszkiwanych przez sekciarzy ${ }^{17}$.

Nasilenie aktywności politycznej obozu politycznego księcia Czartoryskiego w Turcji wymagało nadania jej ram organizacyjnych. Miała je zapewnić utworzona w 1841 r. Wschodnia Agencja Główna. Powołany na stanowisko jej szefa Michał Czajkowski godny jest odnotowania, bo zasłużył się najbardziej w tworzeniu na terenie Turcji polskich oddziałów wojskowych. Pochodzący z Wołynia M. Czajkowski był literatem, którego burzliwe życie wypełniła walka o niepodległość Polski. Wziął udział w powstaniu listopadowym dowodząc oddziałem Kozaków, a potem wyemigrował do Francji, skąd w 1841 r., jako agent księcia Czartoryskiego trafił do Stambułu. Po drodze na placówkę Czajkowski 8 maja 1841 r. wręczył na osobistej audiencji papieżowi Grzegorzowi XVI memoriał w sprawie prześladowań unitów.

15 Tereny te Turcja oddała Rosji na mocy traktatu adrianopolskiego w 1829 r., co doprowadziło do trwającej prawie cztery dekady wojny, zakończonej wysiedleniem ponad połowy tej ludności przez Rosję do Turcji i na Bliski Wschód. Por. Ch. KING, Widmo wolności. Historia Kaukazu, Kraków 2008, s. 81-84. Obliczenia amerykańskiego badacza (podaje liczbę około pół miliona) warto uzupełnić o informację, że proces miał nazwę machadżirstwa i obejmował muzułmanów z kaukaskiego wybrzeża Morza Czarnego: Abchazów, Abazynów, Ubychów, Adygów, Kabardyjczyków.

${ }^{16}$ L. WidersZal, Sprawy kaukaskie, s. 46-48; i dalej rozdział Okres akcji polsko-angielskiej, s. 37-90.

17 A.I. KulBanow, Istorija religioznogo sekstianstwa w Rossii (60-je gody XIX w. - 1917 g.), Moskwa 1965, s. 91-94. Jednym z najlepiej znanych przywódców oddziałów wojskowych złożonych z członków sekt religijnych na Kaukazie był Piotr Wieriagin. 
Polecenie wykonania takiej wyjątkowej misji oznaczało wysokie zaufanie księcia do tego współpracownika ${ }^{18}$.

Książę Adam Jerzy Czartoryski najbardziej cenił potencjalne możliwości poparcia sprawy polskiej przez mocarstwa. Doprowadziło to z czasem do konfliktu z kierującym sprawami polskimi w Turcji agentem M. Czajkowskim, który znacznie lepiej znał realia tureckie od wysłanego tam przez księcia Władysława Zamoyskiego. Różne były możliwości działania obu przebywających w Stambule przedstawicieli księcia. Odmienne też były ich wizje pracy na miejscu. Czajkowski dostrzegał rzeczywisty sens działań Francji i Anglii wobec Polaków i dlatego zdecydował się zabiegać bezpośrednio o wsparcie tureckie. W ten sposób połączył dążenia niepodległościowe Słowian z polityką tego państwa w tzw. turkoslawizm ${ }^{19}$.

O pozycji, jaką M. Czajkowski zdobył w Stambule, celnie napisała badaczka jego losów:

W 1847 roku pozycja Czajkowskiego w Stambule była ugruntowana. Przez agencję i kolonię polską w Adampolu założone zostały podwaliny trwałego stosunku do państwa otomańskiego. Agencja jest przez Turków subwencjonowana. Ze zdaniem Czajki liczą się dygnitarze Porty. Liczy się ambasada francuska. Ma już drogi dojścia nawet do sułtana. Ethem pasza, człowiek z najbliższego otoczenia Abdul-Medżida, jest jego przyjacielem. Bankier Anton i Alleon, mający do sułtana codzienny dostęp, przekazuje wiadomości i sugestie, dzięki czemu Czajce udaje się wywierać wpływ na bieg niejednej sprawy ${ }^{20}$.

Znajomość tureckich realiów, obyczajów i ludzi powodowała, że M. Czajkowski sprawniej niż W. Zamoyski radził sobie w Stambule. Wiele poświęcił, gdyż chcąc uzyskać dostęp do tureckiego władcy, przyjął islam i działał jako Sadyk pasza. Uznał, że daje mu to szczególne prawa i dużą samodzielność, na co nie mógł się zgodzić książę. Dlatego w konflikcie między swoimi dwoma współpracownikami opowiedział się po stronie Władysława Zamoyskiego. Odsunięcie Czajkowskiego od prowadzenia spraw tuż przed wybuchem wojny krymskiej było dużym

18 Sprawę audiencji przedstawiła J. Chudzikowska, Dziwne życie Sadyka Paszy. O Michale Czajkowskim, Warszawa 1971, s. 169-171. Wczesnego okresu życia M. Czajkowskiego dotyczą Pamiętniki opublikowane we Lwowie trzy lata po śmierci autora, w przekładzie z języka rosyjskiego. Prezentują one służbę w wojsku rosyjskim i udział w powstaniu listopadowym; w tym zetknięcie się z carem. Por. Pamiętniki Sadyka Paszy Michała Czajkowskiego, thumaczył na polskie A.P., Lwów 1898.

19 Pojęcie tureckiego slawizmu (turkoslawizmu) za raportem francuskiego dyplomaty wprowadził J. SkowroneK, Kontrowersje wokót Sadyka Paszy: (na marginesie pracy Wandy Smochowskiej-Petrowej, „Michat Czajkowski - Sadyk Pasza i Batgarskoto wazrażdane”, Sofia 1973), „Przegląd Historyczny" 1976, nr 67(4), s. 657-665.

20 J. Chudzikowska, Dziwne życie Sadyka Paszy, s. 275. 
ciosem dla polskich wysiłków. Trudno z tego czynić zarzut księciu, który zdawał sobie sprawę z tego, że o polityce europejskiej decydują mocarstwa, a nie słaba i zależna od nich Turcja. Strata operatywnego współpracownika osłabiała polskie możliwości działania w Turcji ${ }^{21}$.

\section{POLSCY WOJSKOWI NA KAUKAZIE}

Analizując aktywność polskich wojskowych w XIX wieku na muzułmańskim Wschodzie, należy podkreślić kluczowe znaczenie Turcji. Z tego kraju kierowano także ich poczynaniami na Kaukazie. Trzeba wydzielić dwa okresy tych działań, które początkowo w trzeciej i czwartej dekadzie miały charakter prac przygotowawczych, a dopiero w latach 50. przystąpiono do tworzenia polskich oddziałów wojskowych.

W pierwszym okresie polscy oficerowie, którzy za pośrednictwem angielskim trafili do armii tureckiej, wykonywali zadania wywiadowcze i szkoleniowe. Obszarem ich aktywności było pogranicze Kaukazu Południowego, a powodzenie misji wiązali z rachubami na pozyskanie do walki Polaków służących w wojsku rosyjskim. Z misji wynosili wiedzę o regionie, którą potem wykorzystywali do tworzenia planów prowadzenia walki na Kaukazie. Niekiedy były one dość fantastyczne, bo zakładały utworzenie oddziałów, które rewoltując ludy kaukaskie i Kozaków, miały pomaszerować przez Kaukaz i Krym do Polski, aby jej przynieść wolność. Działania te realizowano wspólnie z Anglikami, którzy finansowali wyjazdy Polaków. Równolegle do armii sułtana trafiali polscy wojskowi, którzy jak Józef Bem mieli ogromne zasługi dla jej modernizacji i osiągali najwyższe godności ${ }^{22}$

W grupie polskich wojskowych przebywających w Turcji w intersującym nas okresie trzeba na pierwszym miejscu wymienić dokonania uczestnika powstania listopadowego - Wojciecha Chrzanowskiego. Należał do niewielkiej grupy osób, która poznała tereny nadczarnomorskie wcześniej, uczestnicząc w wojnie rosyjsko-perskiej 1828-1829. Pobyt tego wojskowego w Turcji i na Kaukazie został już wielokrotnie opisany, dzięki pozostawionej bogatej spuściźnie w postaci licznych publikacji. Powiedzmy więc tylko, że W. Chrzanowski przekroczył granicę

21 J. NowaK, Władystaw Zamoyski. O sprawę polska w Europie (1848-1868), Poznań 2002, s. 187-193; rozdział Klopoty z Sadykiem.

${ }^{22}$ Postać J. Bema zasługuje na osobne omówienie, jednak w tym artykule interesują nas działania realizujące plany polskie emigracyjnego ośrodka politycznego wobec Kaukazu. J. Bem w służbie tureckiej politycznie działał ostatnie dwa lata przed śmiercią w 1850 r. na terenie Syrii. 
turecko-rosyjską i opisał stan rosyjskich fortyfikacji. Dostrzegał możliwość wykorzystania mieszkańców Kaukazu w walce z Rosją i w tym celu zabiegał o poparcie angielskie dla toczonej przez nich walki. Wysunął koncepcję utworzenia polskiego legionu do walki na tym terenie, który miało stanowić pięć batalionów ${ }^{23}$.

Podobne dokonania były udziałem grupy polskich oficerów, którzy przeszli podobną drogę, jak Wojciech Chrzanowski. Wymieńmy tylko Ludwika Bystrzonowskiego i Feliksa Breańskiego ${ }^{24}$. Pierwszy po wykonaniu wielu misji zleconych przez Hotel Lambert wstąpił na służbę turecką i otrzymał po wojnie krymskiej, jako jeden z pięciu Polaków, awans generalski. Z kolei Feliks Breański wyemigrował do Francji po powstaniu listopadowym i współpracował z księciem Adamem Jerzym Czartoryskim, organizując w czasie Wiosny Ludów polski legion we Włoszech. Do Turcji trafił w czasie wojny krymskiej i działał wspólnie z L. Bystrzonowskim na pograniczu kaukaskim. Pracując w sztabie armii Ahmeda Reszyda paszy, opracował plan działań przeciw wojskom rosyjskim na froncie kaukaskim. Obaj Polacy wzięli udział w kampanii 1854 r., walcząc z Rosjanami pod Karsem ${ }^{25}$.

Do wojskowych dołączyli w latach 40. emisariusze i agenci księcia Czartoryskiego, którzy obok rozpoznania sytuacji na Kaukazie Południowym, mieli także zadanie nawiązywania kontaktów z przywódcami miejscowej ludności. Dlatego terenem ich aktywności stało się kaukaskie wybrzeże Morza Czarnego - od Abchazji po Czerkiesję. Ta istotna zmiana poszerzyła możliwości działania, bo już po kilku latach podjęto próbę wysyłania tam polskich artylerzystów, którzy mieli wspierać walczących górali obsługując zdobyte przez nich w walce armaty. W taki sposób rozpoczęto w XIX wieku walkę zbrojną z Rosją na Kaukazie.

Polscy emisariusze nie zaniedbywali działań, których celem było pozyskanie Polaków służących na Kaukazie w armii rosyjskiej. O ile nie udało się doprowadzić do przejścia na stronę górali żadnego oddziału, o tyle powodzeniem zakończyły się próby wykupywania z niewoli pojedynczych dezerterów i jeńców. Mimo niezwykle trudnych warunków działania polskich agentów, takie akcje przeprowadzali wysłannicy A.J. Czartoryskiego. Samo wykupienie Polaków było tylko pierwszym

${ }^{23}$ Pisma wojskowo-polityczne podawane rządom polskiemu, angielskiemu, francuskiemu, tureckiemu i piemonckiemu przez Jenerała Wojciecha Chrzanowskiego w okresie czasu od 1830 do 1856 r., wydat i objaśnił zarysami wspótczesnych zdarzeń dziejowych Leon Chrzanowski, t. 1, Kraków 1871; noty z lat 1833-1842 dotyczące sprawy wschodniej w dziale I od s. 15; wyprawa do Aleksandropola - Giumr, s. 92-94.

${ }^{24}$ Gen. Feliks Breański. Autobiografia, opr. J. Frejlich, Kraków 1914. L. Widerszal podał, że w 1834 r. L. Bystrzonowski jako pierwszy podjął próbę przeniesienia polskiej walki z Rosją na Kaukaz. L. Widerszal, Sprawy kaukaskie, s. 51.

${ }^{25}$ H. ChudzIo, Generatowie polscy w obronie twierdzy Kars podczas wojny krymskiej, ,Studia z Historii Społeczno-Gospodarczej” 9(2011), s. 153-172. 
krokiem, bo potem należało zorganizować ich wyjazd do Turcji i pomóc w znalezieniu środków do życia. Badacze historii założonej przez księcia polskiej osady w Turcji podali nawet nazwiska osób, które tą drogą tam trafiły ${ }^{26}$.

Duża, licząca stale kilkadziesiąt tysięcy osób grupa polskich żołnierzy służących na Kaukazie w wojsku rosyjskim, nie przekształciła się w oparcie dla akcji antyrosyjskiej. Trudno określić precyzyjnie liczbę Polaków odbywających służbę w Korpusie Kaukaskim w interesującym nas okresie, bo zmieniała się ona cały czas. Początkowo Rosja wysyłała na Kaukaz z Polski jeńców i osoby skazane za przestępstwa polityczne, które zostały ukarane w ten sposób za walkę z nią. Potem trafiali tam Polacy, których grupa była największa i systematycznie odnawiana przez nowych rekrutów. Z powodu długiego czasu służby wojskowej w wojsku rosyjskim, który od $1834 \mathrm{r}$. wynosił 25 lat, grupa polska w wojsku rosyjskim na Kaukazie co roku się powiększała. Trzeba uwzględnić dwie grupy osób, które nie zawsze są zauważane. Pierwszą stanowili oficerowie i podoficerowie zawodowi, którzy służbę w armii rosyjskiej traktowali jako sposób zarabiania na życie. W drugiej byli mieszkańcy ziem kresowych, których świadomość odrębności narodowej dopiero się rodziła, ale nadal byli uważani za mieszkańców dawnej Rzeczypospolitej ${ }^{27}$.

Dokładne ustalenie liczby Polaków służących w wojsku rosyjskim na Kaukazie w XIX wieku jest niemożliwe bez dostępu do wojskowych archiwów rosyjskich. Polski badacz, badając dostępne polskie dokumenty z tamtego okresu, podał kilka liczb, które warto przytoczyć. Wyjaśniają one, dlaczego zachodni politycy zwrócili uwagę na tych Polaków. W 1812 r. miało trafić na Kaukaz 10 tys. żołnierzy, a w latach 1832-1834 kolejne 9 tys. W drugiej połowie stulecia regularnie Korpus Kaukaski zasilali rekruci z ziem Królestwa Polskiego: w 1844 r. - 732, w 1842 - 931, w 1847 - 953. Podane liczby należałoby jeszcze powiększyć o osoby zesłane do odbycia służby wojskowej przez sądy skazujące na takie wyroki uczestników spisków niepodległościowych. Konsul francuski w Tbilisi miał określić ogólną liczbę Polaków w Korpusie Kaukaskim w roku 1840 na 25-30 tys. ${ }^{28}$

Jednym z Polaków walczących po rosyjskiej stronie frontu kaukaskiego był zesłany do służby w Korpusie Kaukaskim Władysław Jurkowski. Trafił tam w 1838 r.

26 Por. K. DopieraŁa, Adampol-Polonezkoy: z dziejów Polaków w Turcji, Poznań 1983.

${ }^{27}$ L. Widerszal, Sprawy kaukaskie, s. 31-32; tamże omówienie warunków służby Polaków na Kaukazie i problemu dezercji.

${ }^{28} \mathrm{~W}$ nowych opracowaniach toczy się dyskusja na temat wielkości tej grupy. Por. W. CABAN, Stużba rekrutów z Królestwa Polskiego w armii carskiej w latach 1831-1873, Warszawa 1973, s. 114 116; G. PIwnICKI, Polscy wojskowi i zesłańcy w carskiej armii na Kaukazie w XIX $i$ na poczatku XX wieku, Toruń 2001; szacuje, że w interesującym nas okresie, czyli w ciągu 20 lat po powstaniu listopadowym do Korpusu Kaukaskiego trafiło 200 tys. rekrutów z Polski. 
za udział w spisku Szymona Konarskiego. Napisał kilka listów do Pelagii Podhorskiej, w których obok spraw osobistych przedstawił warunki, w jakich odbywał służbę w wojsku rosyjskim na Kaukazie. Był artylerzystą, który odbył kilka ekspedycji na tereny Czerkiesji w latach 1839-1842, czyli w czasie rosnącej tam aktywności agentów księcia A.J. Czartoryskiego. Najobszerniej opisał kampanię z 1839 r., która latem przemierzyła szlak z Kubania ku Morzu Azowskiemu do Anapy. Inna opisana wyprawa z 1841 r. miała za cel abchaskie Suchumi. W listach W. Jurkowskiego znajdujemy wyjaśnienie sposobu prowadzenia operacji wojskowych przez Rosjan, którzy umiejętnie wykorzystywali posiadaną przewagę techniczną. Było to widoczne w wykorzystaniu uzbrojonych w silną artylerię okrętów wojennych, które wspierały operacje lądowe transportując wojska do trudno dostępnych, pozbawionych sieci drogowej górskich regionów nadbrzeżnych ${ }^{29}$.

W latach 40. XIX wieku na Kaukaz coraz częściej trafiali polscy agenci, których wyprawy były bardzo niebezpieczne i często kończyły się tragicznie. Znamy dobrze ich nazwiska i cele misji. Przywołajmy wyprawę do Czerkiesji innego polskiego artylerzysty - Kazimierza Gordona, który według wydanej mu w maju 1846 r. instrukcji miał za zadanie wspierać Czerkiesów swoimi umiejętnościami w walkach, niwelując tym przewagę wojsk rosyjskich. Zginął w niejasnych okolicznościach $^{30}$. Podobnie tragicznie zakończył się wyjazd Aleksandra Korczaka Wereszczyńskiego, który już w 1839 r. zaproponował, że uda się tam, aby nawiązać kontakty z Gruzinami. Dopiero dwa lata później jego misja uzyskała akceptację księcia A.J. Czartoryskiego. Według odnalezionych dokumentów, trasa miała biec od Erzerumu przez Taurys do Teheranu, ledwie zahaczając o kaukaskie prowincje nadkaspijskie Rosji. Wymienione w przywołanych dokumentach nazwy miast uległy pewnym zmianom, z wyjątkiem Erzerumu na Wyżynie Ameńskiej (obecnie w granicach Turcji). Taurus to pasmo górskie w południowej Turcji i miasto u ich podnóża. Leżą one z dala od Gruzji, więc określenie misji mianem gruzińskiej było mało precyzyjne. Zwracając uwagę na brak precyzji w określaniu jej celu trzeba podkreślić, że także ten agent zmarł w niejasnych okolicznościach w podróży ${ }^{31}$.

${ }^{29}$ Biblioteka Kórnicka, rkps 1163, Listy W. Jurkowskiego do Pelagii Podhorskiej, zesłanego w roku 1838, poza tym zesłaniem na Kaukaz, opisujące ekspedycje przez niego odbyte w latach 1839-40-41-42, k. 15-16. Dalej także opis zwyczajów czerkieskich. Analiza korespondencji W. Jurkowskiego w: A. Furier, Polacy w Gruzji, Warszawa 2009, s. 133-134.

${ }^{30} \mathrm{BCz}$, sygn. 5438m, Raport Gordona z 17 lipca 1846 r., k. 227-230. W literaturze kilka wersji jego śmierci - miał zostać zabity przez Ubychów albo przez rosyjskiego agenta - Ormianina.

${ }^{31}$ Ten polski emisariusz był śledzony przez Rosjan, podobnie jak wielu innych. Por. Centralne Archiwum Historyczne Republiki Gruzińskiej, fond 16, opis 1, dieło 6746, Ob razyskie za polskim emissarom Wereszczinskim. Centralne Archiwum Historyczne Republiki Gruzińskiej, fond 4, opis 1. Tamże inne listy gończe za polskimi agentami z tego okresu. 
Liczba dezercji Polaków z Korpusu Kaukaskiego nasiliła się na początku lat 30. XIX wieku. Nie obejmowały one zresztą tylko Polaków, ale także żołnierzy innych narodowości - Rosjan i Małorusinów. Los dezerterów był ciężki, bo bardzo często padali oni ofiarą wewnętrznych sporów plemion kaukaskich albo byli wydawani Rosjanom dla okupu. Wtedy spotykała ich okrutna kara pałek, opisana przez autorów wspomnień z Kaukazu. Słusznie odnotował badający tę problematykę prawie sto lat temu uczony, że Czerkiesi często nie rozróżniali Polaków od Rosjan i biorąc Polaków do niewoli traktowali ich tak samo jak Rosjan. Ci ostatni w przekonaniu, że podanie się za Polaków złagodzi warunki uwięzienia, niekiedy próbowali się w taki sposób ratować.

Kaukazczycy traktowali jeńców surowo i wykorzystywali ich jako niewolniczą siłę roboczą, którą można było handlować lub w razie sprzeciwu zabić. Zachowały się wspomnienia osób, które taką niewolę przeżyły, i warto przywołać choćby jeden przykład, żeby wyjaśnić stosunek górali kaukaskich do Polaków. Dobrym przykładem jest los Karola Kalinowskiego, który do niewoli nie trafił w czasie walk, ale został porwany przez dwóch Czeczenów w czasie przechadzki poza terenem fortecy. Po dowiezieniu go do aułu, w którym został sprzedany za jednego barana, przeszedł przesłuchanie, które pozwoliło określić jego wartość. Pouczono go, że zapłaconą porywaczom cenę musi stokrotnie odpracować lub zapłacą ją w formie wykupu jego bliscy. Inaczej grozi mu śmierć. A oto, jak K. Kalinowski opisał pierwszą noc spędzoną w niewoli: „Na noc mój gospodarz włożył mi na szyję ogromny łańcuch, bojąc się zapewne abym mu nie uciekł i koniec jego przez ścianę do drugiej izby przeciągnął" 32 .

Przedstawiony wyżej stosunek ludności północnokaukaskiej do Polaków był daleki od idealizowanego $\mathrm{w}$ wielu publikacjach obrazu polsko-kaukaskiej przyjaźni i bliskości. Przy tym nie było to wynikiem jakiegoś szczególnego okrucieństwa górali kaukaskich, czy ich wyjątkowej nienawiści do Polaków. Niewolnictwo i porywanie ludzi były elementem kaukaskiej rzeczywistości od wieków, więc w czasie wojny kaukaskiej korzystano z możliwości, jakie w tej dziedzinie się pojawiły. Mało znanym faktem $\mathrm{z}$ historii regionu jest funkcjonowanie targów niewolników na Kaukazie aż do połowy XIX wieku. Zacytowany K. Kalinowski odnalazł potem w niewoli swoje miejsce i w dalszej części swoich wspomnień wyraził wiele dobrych opinii o Czeczenach.

Potwierdzenie przedstawionych we wspomnieniach Polaków zesłanych na Kaukaz i w pismach polskich agentów problemów, można uzyskać także w dokumentach angielskich. Agenci angielscy wysłani do Turcji i na Kaukaz, w latach

${ }^{32}$ K. Kalinowski, Pamiętniki mojej żolnierki na Kaukazie i niewoli u Szamila. Od roku 1844 do 1854, wstęp W. Dawid, Warszawa 1883, s. 52, reprint: Warszawa 2017. 
30. XIX wieku zabiegali o pozyskanie do walki z Rosją żołnierzy przebywających w niewoli u plemion kaukaskich. Było to widoczne w tym czasie z powodu nasilenia się liczby dezercji, co jednak szybko zostało zahamowane przez okrutne represje ze strony dowódców rosyjskich i sposób traktowania dezerterów w niewoli. Na propozycje Anglików dotyczące wydania Polaków, Czerkiesi odpowiedzieli propozycją sprzedaży polskich żołnierzy, licząc sobie po cztery funty za głowę ${ }^{33}$.

\section{POLSKI ODDZIAŁ I JEGO WALKA NA KAUKAZIE}

Przygotowania do wojny krymskiej, która wybuchła w 1853 r., umożliwiły Polakom sformowanie w Turcji oddziałów wojskowych, które wzięły udział w walkach na froncie bałkańskim. Dzieje pułków kozaków sułtańskich i dywizji Władysława Zamoyskiego są dobrze opracowane. Ich działania na froncie bałkańskim nie przyniosły korzystnych rozstrzygnięć w sprawie polskiej. Pod znakiem zapytania postawiło to polską aktywność militarną na terenie Turcji. Mimo to znaleźli się ludzie gotowi ją kontynuować. Na ich czele stanął Teofil Łapiński - powstaniec węgierski 1848 r., który umiejętności wojskowe zdobył wcześniej w armii austriackiej. Na emigracji związał się z Hotelem Lambert i na jego polecenie wyjechał do Turcji, gdzie, aby uzyskać poparcie tureckie, przyjął islam i imię Tefik bej. Karierę wojskową na Wschodzie rozpoczął, jako major, od służby w utworzonej przez W. Zamoyskiego dywizji kozaków sułtańskich. Znalazł się w niewielkiej grupie wyższych oficerów, którzy zostali awansowani 30 lipca 1856 r. do stopnia podpułkownika ${ }^{34}$.

Po zakończeniu wojny krymskiej Władysław Zamoyski zatroszczył się o losy żołnierzy z likwidowanej dywizji, którą dowodził. Mieli oni do wyboru - pozostanie w Turcji lub wyjazd do państw zachodnich. W koszarach pojawili się też agenci czerkiescy, proponujący Polakom służbę najemną w walce z Rosjanami na Kaukazie. Według badaczy tej problematyki, w sierpniu 1856 r. zgłosiło się tylko 76 żołnierzy, którzy podpisali umowy i otrzymali pieniądze. Przedsięwzięcie miał sfinansować pozostający na służbie sułtańskiej Czerkies - Izmail pasza ${ }^{35}$. Zapewne jesienią uzupełniono stan osobowy oddziału, bo w lutym 1857 r. do zaokrętowa-

${ }^{33}$ L. WidERSZAL, Sprawy kaukaskie, s. 81. Na temat zwyczajów Czerkiesów ukazał się niedawno interesujący artykuł: N. TAYLOR-TERLECKA, W oczach Zachodu: scenki z życia domowego Czerkiesów (na podstawie relacji podróżników), „Pro Georgia. Journal of Kartvelological Studies” 2015, nr 25, s. 205-217.

34 J. NowaK, Władysław Zamoyski, s. 218-234.

${ }^{35}$ W literaturze przedmiotu istnieją duże rozbieżności dotyczące wielkości oddziału T. Łapińskiego. Cytowana wyżej badaczka twierdzi, że liczył 72 osoby. J. NowAK, Władysław Zamoyski, s. 235. Inni badacze podają liczby większe - od stu do dwustu osób. Brak precyzji wynika z pomie- 
nia gotowych było ponad dwustu żołnierzy i oficerów, z czego $76 \mathrm{w}$ grupie T. Łapińskiego i 130 ludzi w oddziale dowodzonym przez majora Józefa Jagmina. Ta druga grupa nie popłynęła ostatecznie na Kaukaz i została w Stambule, ponieważ finansujący wyprawę Czerkies nie dostarczył obiecanej broni i wyposażenia. Nawet $\mathrm{z}$ ubiorem były problemy, ale w tej sprawie potajemnie pomógł W. Zamoyski, zgadzając się na przekazanie resztek sortów mundurowych z magazynów likwidowanej polskiej dywizji kozaków sułtańskich. Trzeba bowiem pamiętać, że sytuacja polityczna była dla wyprawy $\mathrm{T}$. Łapińskiego niekorzystna. Zmęczona wojną krymską Europa chciała pokoju z Rosją, a utworzenie przez Polaków oddziału do walki na Kaukazie wywołało ostry sprzeciw rosyjski. Zmusiło to władze tureckie do powołania komisji, która zajęła się wyjaśnianiem sprawy, przesłuchując przebywających w Stambule polskich przywódców z W. Zamoyskim na czele ${ }^{36}$.

Przebieg wyprawy oddziału Teofila Łapińskiego został przedstawiony w popularnonaukowej, nie wolnej od błędów i pomyłek, publikacji. Ukazuje ona mimo pewnych mankamentów rzeczywisty obraz zrealizowanych na Kaukazie działań. Zacznijmy od tego, że oddział już na etapie formowania spotkał się z ostrym przeciwdziałaniem rosyjskich dyplomatów przebywających w Stambule. Polacy nie otrzymali obiecanej broni i dlatego nie mogli osiągnąć sukcesu militarnego. Z konieczności T. Łapiński organizował więc wypady kilkunastoosobowych patroli, zabiegając o pozyskanie miejscowych plemion. Dla porównania, wysłany wtedy na tereny czerkieskie korpus rosyjski liczył kilka tysięcy żołnierzy. Polacy nie otrzymali także obiecanej wcześniej aprowizacji, co skutkowało problemami z wyżywieniem. Fatalne warunki pobytu doprowadziły do buntu podwładnych i uwięzienia Łapińskiego. Dowództwo objął po nim porucznik Michał Marecki. Po jakimś czasie T. Łapiński odzyskał wolność, ale nie był w stanie kontynuować walki na Kaukazie. Do Stambułu powrócił bez sukcesów, z pięcioma żołnierzami pod koniec stycznia 1860 r. $^{37}$

Niepowodzenie trwającej prawie trzy lata wyprawy nie zniechęciło T. Łapińskiego do kontynuowania współpracy z Czerkiesami. Mimo wielu zarzutów pod jego adresem ze strony działaczy emigracyjnych, pułkownik nadal działał. Dlatego już kilka miesięcy po powrocie do Stambułu podjął kolejną próbę stworzenia polskiego oddziału do walki z Rosją na terenie Kaukazu. Trudno zinterpretować to posunięcie, realizowane tuż po poniesionej porażce. Najpewniej uważał, że zawiedli kaukascy sojusznicy, ale sprawa jest ważniejsza niż osobiste emocje i urazy,

szania wielkości sformowanego oddziału z tym, który wyjechał, a potem działał na miejscu, gdzie dołączyli do niego dezerterzy.

36 J.S. ŁąTKa, Romantyczny kondotier, Katowice 1988, s. 48-51.

37 Tamże, s. 71-132. 
więc trzeba zadbać o wsparcie potężniejszych sojuszników, posiadających fundusze konieczne do kontynuowania walki. Dlatego po krótkich rokowaniach podpisał w imieniu księcia Adama Jerzego Czartoryskiego z Mehmetem Eminem paszą umowę, która miała 15 artykułów. Określały one charakter i zadania polskiego oddziału, mającego rozpocząć służbę 1 kwietnia $1860 \mathrm{r}$. Dalej podano datę zakończenia służby -1 kwietnia 1863 r. oraz warunki odbycia jej przez polskich żołnierzy. Oddział miał istnieć trzy lata, a jego dowódcę mianował książę Adam Jerzy. Nie analizując szczegółowo całości, przytoczymy tylko artykuł pierwszy tego dokumentu, w którym stwierdzano, że: „Jego Ekscelencja Mehmet Emin pasza zgadza się na formacye oddziału polskiego pod znakami narodowemi i prawami własnemi”"38.

Teofil Łapiński chciał kontynuować walkę z Rosją na Kaukazie, ale do tego potrzebne były środki. Zapewne szukając ich, przyjął zaproszenie Dawida Urquharta i udał się w 1862 r. do Londynu z delegacją czerkieską, którą kierowali Hadżi Hajder Hassan i Kustan Ogly. Przywódcy czerkiescy złożyli wizytę lordowi Henry’emu Johnowi Palmerstonowi i przedstawili prośbę o wsparcie ich walki z Rosją. Wydarzenia te obszernie relacjonowała prasa londyńska ${ }^{39}$. W zmienionej sytuacji politycznej Wielka Brytania po zawarciu korzystnego pokoju z Rosją nie była zainteresowana popieraniem walk na Kaukazie. Zdobycie Achulgo przez Aleksandra Barjatyńskiego i wzięcie do niewoli Szamila w 1859 roku położyło zasadniczemu okresowi wojny kaukaskiej i polskim planom walki z Rosją na Kaukazie ${ }^{40}$. Czerkiesi wrócili więc z niczym, a T. Łapiński zajął się organizowaniem pomocy dla powstania styczniowego, które wybuchło w Polsce. Kierując wyprawą parowca „Ward Jackson”, wiozącego zakupioną na zachodzie broń do Polski, zyskał sławę i uznanie ${ }^{41}$.

Wieloletnie kontakty z Kaukazczykami mieszkającymi w Stambule i pobyt na Kaukazie umożliwił T. Łapińskiemu zebranie informacji, które wykorzystał po powrocie do kraju przy pisaniu nader interesującej książki, poświęconej walce o wolność ludów górskich na Kaukazie. Był to jego największy sukces, bo wydana w ję-

${ }^{38}$ BCz, rkps 5612 IV, Ugoda między Jego Excelencyą Mehemet Emin Paszą a Pułkownikiem Teofilem Łapińskim (Tefik Bey) w imieniu J.K.M. Jaśnie Oświeconego Księcia Adama Czartoryskiego, k. 279-280. Zapisów tej umowy nie zrealizowano.

${ }^{39}$ Ch. KING, Widmo wolności, s. 117.

40 Podpisany 30 marca 1856 r. traktat paryski kończył trwające 25 lat obrady. Nakazywał Rosji zwrócenie Turcji Karsu, a Mołdawii części Besarabii. Morze Czarne zamknięto dla okrętów wojennych i zakazano rozbudowy infrastruktury wojskowej na jego wybrzeżu tureckim i rosyjskim. Wprowadzono wolność żeglugi na Dunaju. Mołdawia i Wołoszczyzna pozostały tureckimi protektoratami, zaakceptowano politykę wewnętrzną sułtana w sprawach wolności religijnej. Był to polityczny sukces Zachodu i Turcji, a przegrana Rosji.

${ }^{41}$ T. Łapiński opisał to w opublikowanych później wspomnieniach: Powstańcy na morzu w wyprawie na Litwę. Z pamiętników pułkownika P. Łapińskiego, Lwów 1879. 
zyku niemieckim publikacja została uznana za szczytowe osiągnięcie propagandy sprawy kaukaskiej na Zachodzie ${ }^{42}$.

Wyprawa kaukaska Teofila Łapińskiego warta jest odnotowania nie z powodu dokonań militarnych, których zabrakło. Stanowiła uwieńczenie kilku dekad przygotowań do przeniesienia na Kaukaz walki zbrojnej, prowadzonej przez polskich żołnierzy o niepodległość Polski. W takiej szczątkowej formie zrealizowano utworzenie polskiego legionu na Kaukazie. W czasie powstania styczniowego próbowano ostatni raz wykorzystać Kaukaz do wzniecenia antyrosyjskiego powstania, który odciążyłby walczących w Polsce. Jednakże wysłany tam 31 sierpnia $1863 \mathrm{r}$. ze Stambułu kilkunastoosobowy oddział, dowodzony przez Klemensa Przewłockiego, musiał się szybko wycofać, nie realizując postawionego zadania ${ }^{43}$.

\section{PODSUMOWANIE}

Zakończenie wojny kaukaskiej w 1864 r. i podporządkowanie całego regionu Rosji wyznaczyło ostatecznie kres polskim zabiegom o wykorzystanie go w polskiej walce o niepodległość. Przedstawione w artykule starania stanowią niezwykle ciekawy przykład próby umiędzynarodowienia sprawy polskiej w oparciu o wrogie od niedawna polskie mocarstwo - Turcję. Elementem niezwykle utrudniającym zbliżenie polsko-tureckie była różnica religii, co zmuszało wielu polskich patriotów do podejmowania pod presją władz tureckich decyzji o konwersji wyznaniowej. Nie było to dobrze odbierane przez polską opinię publiczną, a miało także znaczenie dla próby przyciągnięcia do akcji antyrosyjskiej Polaków służących w wojsku rosyjskim. Władze Rosji bardzo intensywnie działały w pierwszej połowie XIX wieku na rzecz zbliżenia z papiestwem, co doprowadziło do podpisania konkordatu. Umożliwiło to przydzielenie do Korpusu Kaukaskiego kapelanów katolickich i kreowanie się przed żołnierzami na obrońców chrześcijaństwa przed naporem islamu. To niedoceniana, a bardzo ważna przyczyna niepowodzenia antyrosyjskiej akcji agentów zachodnich na Kaukazie ${ }^{44}$.

Z perspektywy czasu można wskazać liczne słabości działań podejmowanych przez Polaków na terenie Turcji i sąsiadującego z nią Kaukazu w XIX wieku. Napisane przez polskich wojskowych plany włączenia Kaukazu do polskiej walki

42 Por. T. ŁAPIŃSKI, Die Bergvölker des Kaukasus und ihre Freiheitskampf, Hamburg 1863. Książkę określono mianem najbardziej prokaukaskiego dzieła tego czasu.

${ }^{43}$ Polski Stownik Biograficzny, t. XXIX, Wrocław 1986, s. 26-27. Przedstawiono tam szczegółowo przebieg tej krótkiej wyprawy na Kaukaz latem $1863 \mathrm{r}$.

${ }^{44}$ Por. A. Furier, Polacy w Gruzji, s. 231-237; rozdział Działalność kapelanów wojskowych. 
powstańczej, charakteryzowały się wielką wyobraźnią ich twórców, dorównującą rozmiarowi niewiedzy o kaukaskiej rzeczywistości. Najlepiej pokazuje to stosunek tych wojskowych i agentów do ludów kaukaskich i Kozaków, traktowanych jako monolit. W obu przypadkach oznaczało to popełnienie kardynalnego błędu w założeniach wstępnych. Zarówno grupa kozacka, jak mieszkańcy Kaukazu byli wewnętrznie podzieleni i nieuwzględnienie tego elementu skazywało wszelkie plany i podejmowane działania na niepowodzenie ${ }^{45}$.

Uwieńczeniem starań o przeniesienie walki zbrojnej z Rosją na ziemie kaukaskie było wysłanie tam w 1857 r. oddziału Teofila Łapińskiego. Wyprawa ta ze względu na rozmiary przeprowadzonej akcji, fatalną organizację i niekorzystny czas końca wojny kaukaskiej była skazana na kleskę. Czy jednak niepowodzenie tej akcji militarnej powinno dyskredytować samą koncepcję prowadzenia walki zbrojnej z Rosją przez Polaków na Kaukazie XIX wieku? Z pewnością nie, bo koncepcja była warta uwzględnienia i dowodziła determinacji polskich działaczy niepodległościowych skupionych wokół księcia Adama Jerzego Czartoryskiego. Korzystanie ze wparcia angielskiego i francuskiego w tych działaniach pozwalało podtrzymywać zainteresowanie europejskich polityków sprawą polską. Możemy przyjąć, że niepowodzenia w realizacji poszczególnych zamierzeń w terenie były ceną za możliwość kontynuowania przez Polaków współpracy z mocarstwami. Pobocznym, ale ważnym elementem tych działań było zbliżenie z politykami tureckimi i kaukaskimi, którzy nawiązali w następnym stuleciu do tej tradycji współpracy z Polską.

\section{BIBLIOGRAFIA}

\section{Żródła}

Biblioteka Książąt Czartoryskich, sygn. 5437, Kaukaz 1843-1849, Podanie Zwierkowskiego o zwolnienie ze służby.

Biblioteka Książąt Czartoryskich, sygn. 5539 III, pudło 219, Korespondencja księcia Adama Czartoryskiego.

Biblioteka Książąt Czartoryskich, sygn. 5438m, Raport Gordona z 17 lipca 1846 r., k. 227230.

Biblioteka Książąt Czartoryskich, rkps 5612 IV, Ugoda między Jego Excelencyą Mehemet Emin Paszą a Pułkownikiem Teofilem Łapińskim (Tefik Bey) w imieniu J.K.M. Jaśnie Oświeconego Księcia Adama Czartoryskiego.

${ }^{45}$ A. FurIer, Kozacy w społeczeństwie rosyjskim, „Przegląd Zachodni” 1998, nr 2(287), s. 211246. Rosja w tym czasie stworzyła z niepokornych wcześniej kozaków wojska kozackie, włączając je do systemu bezpieczeństwa państwa. 
Biblioteka Kórnicka, rkps 1163, Listy W. Jurkowskiego do Pelagii Podhorskiej, zesłanego w roku 1838, poza tym zesłaniem na Kaukaz, opisujące ekspedycje przez niego odbyte w latach 1839-40-41-42.

Centralne Archiwum Historyczne Republiki Gruzińskiej, fond 16, opis 1, dieło 6746, Ob. razyskie za polskim emissarom Wereszczinskim.

Gen. Feliks Breański. Autobiografia, oprac. J. Frejlich, Kraków: G. Gebethner i Spółka 1914.

KalinowsKi K., Pamiętniki mojej żołnierki na Kaukazie i niewoli u Szamila. Od roku 1844 do 1854, wstęp W. Dawid, Warszawa 1863, reprint: Dialog 2017.

Muzeum Historyczno-Etnograficzne w Zugdidi, List księcia Adama Czartoryskiego do księżnej Nino z 31 maja 1806 r., zbiór rękopisów.

Pamiętniki Sadyka Paszy Michała Czajkowskiego, tłumaczył na polskie A.P., Lwów: Księgarnia Gubrynowicza \& Schmidta 1898.

Pisma wojskowo-polityczne podawane rządom polskiemu, angielskiemu, francuskiemu, tureckiemu i piemonckiemu przez Jenerała Wojciecha Chrzanowskiego w okresie czasu od 1830 do 1856 r., wydał i objaśnił zarysami współczesnych zdarzeń dziejowych Leon Chrzanowski, Kraków: Drukarnia „Czasu” 1871.

Powstańcy na morzu w wyprawie na Litwę. Z pamiętników pułkownika P. Łapińskiego, Lwów: F.H Richter 1879.

\section{Opracowania}

Bliski Wschód - czynniki i skutki destabilizacji, red. B. Grenda, J. Marszałek-Kawa, Toruń: Wydawnictwo Adam Marszałek 2018.

CABAN W., Służba rekrutów z Królestwa Polskiego w armii carskiej w latach 1831-1873, Warszawa 1973.

Chudzikowska J., Dziwne życie Sadyka Paszy. O Michale Czajkowskim, Warszawa: PIW 1971.

Chudzio H., Generałowie polscy w obronie twierdzy Kars podczas wojny krymskiej, „Studia z Historii Społeczno-Gospodarczej" 9(2011).

Dopierala K., Adampol-Polonezkoy: z dziejów Polaków w Turcji, Poznań: Wydawnictwo Naukowe UAM 1983.

FurIER A., Czeczenia i jej mieszkańcy w oczach Polaków, „Etnografia Polska” 41(1997), Z. $1-2$.

FURIER A., Historyczne aspekty kulturowego zróżnicowania Kaukazu, „Sprawy Narodowościowe" (Seria nowa) 2000, z. 16-17.

FurIER A, Kozacy w społeczeństwie rosyjskim, „Przegląd Zachodni” 1998, nr 2(287).

Furier A., Polacy w Gruzji, Warszawa: TRIO 2009.

FurIER A., Polskie ślady w czeczeńskiej historii, „Przegląd Polonijny” 21(1995), z. 3(77).

FurIER A., Wielokulturowość Kaukazu. W poszukiwaniu genezy zróżnicowania kulturowego regionu, „Sprawy Narodowościowe” (Seria nowa) 1999, z. 14-15.

KalembKa S., Wielka Emigracja. Polskie wychodźstwo polityczne w latach 1831-1862, Warszawa: Państwowe Wydawnictwo Wiedza Powszechna 1971.

KING Ch., Widmo wolności. Historia Kaukazu, Kraków: Wydawnictwo Naukowe UJ 2008. 
KLIBANOw A.I., Istorija religioznogo sekstianstwa w Rossii (60-je gody XIX w. - 1917 g.), Moskwa: Wydawnictwo „Nauka” 1965.

KonopCZyŃSKi W., Polska a Turcja 1683-1792, Warszawa: Instytut Wschodni 1936, reprint: Kraków, Muzeum Historii Polski 2013.

ŁAPIŃSKI T., Die Bergvolker des Kaukasus und ihre Freiheitskampf, Hamburg: Hoffman und Dampe 1863.

ŁĄTKA J.S., Romantyczny kondotier, Katowice: Wydawnictwo „Śląsk” 1988.

NowaK J., Władysław Zamoyski. O sprawę polską w Europie (1848-1868), Poznań: Wydawnictwo Poznańskie 2002.

PACHOŃSKi J., Generał Jan Henryk Dąbrowski 1755-1818, Warszawa: Wydawnictwo MON 1985.

PIWNICKI G., Polscy wojskowi i zesłańcy w carskiej armii na Kaukazie w XIX i na początku XX wieku, Torun: Wydawnictwo Adam Marszałek 2001.

ReYCHMAn J., Życie polskie w Stambule w XVIII wieku, Warszawa: PIW 1959, s. 217-241.

RoszczYN M., Islam w Rosji: umma dopiero się rodzi, „Nowa Polityka Wschodnia” 2013, nr 3-4.

Skowronek J., Kontrowersje wokół Sadyka Paszy: (na marginesie pracy Wandy Smochowskiej-Petrowej, „Michał Czajkowski - Sadyk Pasza i Bałgarskoto wazrażdane”, Sofia 1973), „Przegląd Historyczny” 1976, nr 67(4).

SKowroneK J., Polityka bałkańska Hotelu Lambert 1833-1856, Warszawa: UW 1976.

Systemy polityczne i kultura prawna państw azjatyckich, red. J. Marszałek-Kawa, M. Bidziński, Toruń: Wydawnictwo Adam Marszałek 2018.

TAYLOR-TERLECKA N., W oczach Zachodu: scenki z życia domowego Czerkiesów (na podstawie relacji podróżników), „Pro Georgia. Journal of Kartvelological Studies” 2015, nr 25.

Urquhart D., The secret of Russia in the Caspian and Euxine. The Circassian war as affecting the insurrection in Poland 1863 (unknown binding); reprint Franklin Classics Trade Press 2019.

WerESZYCKI H., Stosunki Hotelu Lambert z Hercenem i Bakuninem w przeddzień powstania styczniowego, „Przegląd Historyczny” 1957, nr 2.

Widerszal L., Sprawy kaukaskie w polityce europejskiej w latach 1831-1864, Warszawa: Towarzystwo Naukowe Warszawskie 1934, reprint: Warszawa: Wydawnictwo Neriton 2011.

ŻurawsKi vel Grajewski R., Kaukaz w „dyplomacji” księcia Adama Jerzego Czartoryskiego w okresie kryzysu wschodniego (1832-1840), „Przegląd Nauk Historycznych” 2(2003), nr 2(4). 


\section{KAUKAZ W POLSKICH PLANACH WALKI O NIEPODLEGŁOŚĆ W XIX WIEKU}

\section{Streszczenie}

Imperialna polityka Cesarstwa Rosyjskiego doprowadziła pod koniec XVIII i na początku XIX wieku do zaboru przez to państwo części ziem polskich i Kaukazu. Dostrzegli to polscy politycy emigracyjni, którzy postanowili wykorzystać Kaukaz w walce o niepodległość Polski. W tym celu potrzebne było zbliżenie do Turcji, co pozostawało zbieżne z kierunkiem polityki zachodnich mocarstw - Anglii i Francji, dążących do powstrzymania rosyjskiej ekspansji w Europie i na Bliskim Wschodzie. Opierając się na wsparciu mocarstw zachodnich, wysłannicy kierującego polską polityką emigracyjną księcia Adama Jerzego Czartoryskiego rozwinęli w Turcji działalność skierowaną przeciw Rosji. Artykuł prezentuje polskie działania, których celem było przeniesienie walki o niepodległość na Kaukaz. Ich szczególne nasilenie przypada na okres między powstaniami listopadowym i styczniowym.

Modernizująca się w XIX wieku Turcja potrzebowała kadrowego wsparcia, które zaoferowali jej Polacy. Ceną za możliwość działania w Turcji była często konwersja wyznaniowa na islam, co dla wielu Polaków stanowiło ogromny problem. Mimo to polscy wojskowi reformowali turecką armię i dowodzili jej oddziałami. Działając na terenie Turcji, stworzyli też plany walki o niepodległość uwzględniające wykorzystanie sił antyrosyjskich na Bałkanach i Kaukazie. Otworzyło to drogę do utworzenia tam polskich oddziałów wojskowych, które podjęły walkę z Rosją podczas wojny krymskiej i po niej. W artykule zaprezentowano zabiegi polskich wojskowych i emisariuszy wysyłanych przez Hotel Lambert na Kaukaz, wśród których największe zasługi miał Michał Czajkowski oraz generałowie: Wojciech Chrzanowski, Feliks Breański i Ludwik Bystrzonowski. Dopiero jednak w 1857 r. pułkownik Teofil Łapiński stworzył oddział wojskowy, który podjął walkę z wojskiem rosyjskim na Kaukazie.

Artykuł podejmuje próbę krytycznej analizy dorobku, która obejmuje dwa elementy. Pierwszym polskim jest polemika z funkcjonującymi w Polsce stereotypami na temat Kaukazu. Drugim - zestawienie dotychczasowych ustaleń ze źródłami wytworzonymi w XIX wieku po rosyjskiej stronie frontu kaukaskiego przez polskich zesłańców i rosyjskie instytucje. Oba prowadzą do wniosku, że mimo niepowodzenia polskiej akcji militarnej na Kaukazie, podjęcie tam działań dowodzi determinacji i rozległości horyzontów myślowych polskich środowisk niepodległościowych w XIX wieku.

Słowa kluczowe: Kaukaz; Polska; Turcja; walka o niepodległość; Hotel Lambert; XIX wiek

\section{CAUCASUS IN POLISH PLANS FOR THE FIGHT FOR INDEPENDENCE IN THE NINETEENTH CENTURY}

\section{Sum mary}

The imperial policy of the Russian Empire led to the annexation of part of the Polish lands and the Caucasus by the end of the $18^{\text {th }}$ and the beginning of the $19^{\text {th }}$ century. This was noticed by 
Polish emigre politicians who decided to use the Caucasus in the fight for Polish independence. To this end, it was necessary to get closer to Turkey, which coincided with the direction of the policy of the Western powers - England and France, striving to stop Russian expansion in Europe and the Middle East. Based on the support of the Western powers, the envoys of Adam Jerzy Czartoryski, who runs the Polish emigre policy, have developed activities in Turkey against Russia. The article presents Polish actions aimed at transferring the struggle for independence to the Caucasus. Their particular intensity falls on the period between the November and January uprisings in Poland.

Modernizing in the nineteenth century, Turkey needed the staff support that the Poles offered to her. The price for the possibility of acting in Turkey was often religious conversion to Islam, which for many Poles was a huge problem. Nevertheless, the Polish military reformed the Turkish army and commanded its troops. Operating in Turkey, they also created plans for the fight for independence, taking into account the use of anti-Russian forces in the Balkans and the Caucasus. This opened the way to the creation of Polish military units there, which took up the fight there with Russia during the Eastern War and after it. The article presents the treatment of Polish military and emissaries sent by Hotel Lambert to the Caucasus, among whom the greatest merit was given to Michał Czajkowski and generals: Wojciech Chrzanowski, Feliks Breański and Ludwik Bystrzonowski. However, it was not until 1857 that Colonel Teofil Łapiński created a military unit that fought with the Russian army in the Caucasus.

The article attempts a critical analysis of the achievements, which includes two elements. The first is the polemic with the stereotypes in Poland about the Caucasus. The second is the comparison of the existing arrangements with sources produced in the nineteenth century on the Russian side of the Caucasian front by Polish exiles and Russian institutions. Both lead to the conclusion that despite the failure of the Polish military action in the Caucasus, taking action there proves the determination and vastness of the intellectual horizons of Polish independence environments in the nineteenth century.

Key words: Caucasus; Poland; Turkey; the fight for the independence; Hotel Lambert; $19^{\text {th }}$ century 